\title{
The Fund's Income Position for FY 2009-Midyear Review
}




\title{
INTERNATIONAL MONETARY FUND
}

\section{The Fund's Income Position for FY 2009—Midyear Review}

\author{
Prepared by the Finance Department
}

In consultation with the Legal Department and the Office of Budget and Planning

Approved by Andrew Tweedie

December 5, 2008

Contents

Page

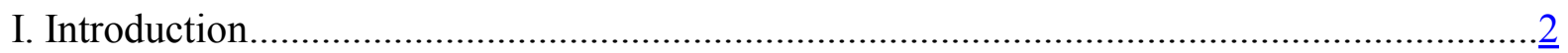

II. Updated FY 2009 Income Position ..............................................................................

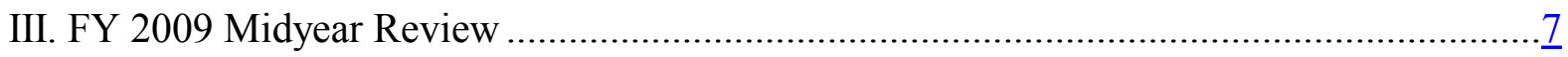

Tables

1. Projected Income Position-FY 2009 ………….......................................................

2. Projected Income and Expenditures......................................................................

3. FY 2009 Burden Sharing Adjustments ..................................................................

Boxes

1. Executive Board Decisions in Effect Related to the FY 2009 Income Position.......................

Annexes

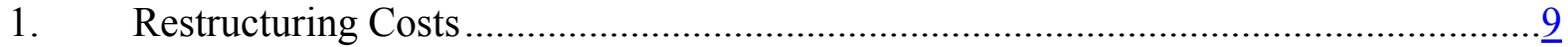

2. $\quad$ Projected Income and Expenses-FY 2009........................................................11

3. Assumptions Underlying the FY 2009 Projections................................................

4. Recent Average Burden Sharing Rates and FY 2009 Quarterly Rates ........................13 


\section{INTRODUCTION}

1. This paper reviews the outlook for the Fund's income position for the financial year 2009 taking into account developments through the first half of the year. The FY 2009 income outlook has improved, mainly as a result of new lending activity associated with the turmoil in global financial markets, together, to a lesser extent, with stronger-thanprojected returns in the Investment Account (IA) in the first half of the financial year. The updated projections indicate that the net income position would be slightly positive in FY 2009. However, the actual outcome remains subject to considerable uncertainty related to the timing and amounts of disbursements under current arrangements, as well as potential new arrangements and the performance of the IA.

2. The paper also provides the basis for the mid-year review of the Fund's income. In April, the Executive Board reached broad agreement on a new framework for setting the rate of charge and also agreed that the margin for FY 2009 would be 100 basis points above the SDR interest rate. ${ }^{1}$ The margin was adopted under the exceptional circumstances clause of the existing Rule I-6(4), and a decision adopting a new Rule I-6(4) was postponed until the work on charges and maturities and precautionary balances has been completed (see Box 1). Thus, the exceptional circumstances clause of Rule I-6(4) continues to apply and, under this clause, a review of the Fund's income at midyear is required.

3. The paper is structured as follows: Section II provides an update on the FY 2009 income position, including restructuring costs, based on the actual outturn for the first half of the financial year and projected developments in the second half of FY 2009. Section III discusses the margin for the rate of charge and burden sharing adjustments, in light of updated projections for FY 2009.

\footnotetext{
${ }^{1}$ See Review of the Fund's Income Position for FY 2008 and FY 2009 (4/15/08).
} 


\section{Box 1. Executive Board Decisions in Effect Related to the FY 2009 Income Position $^{1}$}

The Executive Board has taken the following decisions affecting the Fund's income position for FY 2009:

\section{Rate of Charge}

The margin for calculating the rate of charge in FY 2009 was set at 100 basis points. This decision was adopted under the exceptional circumstances clause of Rule I-6(4).

\section{Rule I-6(4)}

In exceptional circumstances the margin for calculating the rate of charge may be set on a basis other than the estimated income and expense of the Fund and a target amount of net income for the year. A midyear review of the income position shall be held to decide whether (i) "the exceptional circumstances" under which the margin has been determined have changed, and (ii) the margin over the SDR interest rate under Rule T-1 determined under Rule I-6(4)(a) shall be changed in light of the actual income position for the first six months of the financial year.

\section{PRGF-ESF Administrative Expenses}

Beginning the financial year in which the Fund adopts a decision authorizing the sale of postSecond Amendment gold, the Fund will resume annual reimbursements of the GRA in respect of the expenses of conducting the business of the PRGF-ESF Trust.

\section{Burden Sharing for Deferred Charges}

Income losses resulting from unpaid charges are shared equally between the debtor and creditor members under the burden sharing mechanism largely pursuant to a decision taken in 2000. Unless amended by the Board, this mechanism will continue for as long as overdue obligations to the Fund persist.

\footnotetext{
${ }^{1}$ See Review of the Fund's Income Position for FY 2008 and FY 2009 (4/15/08).
}

\section{UPDATED FY 2009 InCOME PoSition}

\section{The updated outlook for FY 2009 projects net income of about SDR 7 million} after taking into account restructuring costs. ${ }^{2}$ This compares with a shortfall of about SDR 190 million envisaged at the beginning of the financial year (see Table 1).

5. On the income side, the improved outlook mainly reflects higher income from lending and, to a lesser extent, investment returns:

- $\quad$ New lending activity. In the first half of the year, income from lending was broadly in line with the full year projection. However, the sharp pickup in Fund lending that

\footnotetext{
2 The Board approved a budget appropriation of US\$185 million (about SDR 115 million) for FY 2008-11 to fund the costs of institutional restructuring. See Annex 1 for a discussion of the treatment of restructuring costs.
} 
began in October is estimated to result in additional Fund income of around SDR 160 million. This would comprise some SDR 70 million in service charges, SDR 40 million in level-based surcharge income, and SDR 50 million from the margin on the rate of charge. ${ }^{3}$

- Higher investment returns. In the six months through end-October, the return of the IA has been higher than expected, reflecting the flight-to-quality in global financial markets. IA income at end-October was SDR 173 million compared to an initial projection of SDR 194 million for the full year. Overall, the IA returned 2.93 percent (net of fees), exceeding the SDR interest rate by 152 basis points in the first half of the year. The updated projection for FY 2009 assumes an indicative additional 50 basis points in returns over the SDR interest rate during the second half. ${ }^{45}$ However, IA performance could be weaker going forward if part of the recent extraordinary decline in bond yields is reversed as market conditions stabilize.

- Lower implicit returns on interest-free resources. Implicit returns from the GRA's interest-free resources, which broadly approximate the SCA-1 balances, are projected to be lower by about SDR 6 million. This reflects the lower projected average SDR interest rate for FY 2009 of 2.20 percent, compared with the initial projection of 2.75 percent.

- $\quad$ Reimbursement of expenses. No change has been made to the projection for reimbursement to the GRA of the costs of administering the PRGF-ESF Trust, which will begin in the financial year in which the Fund adopts a decision authorizing the sale of post-Second Amendment gold (see Box 1).

\section{Expenditures are projected to be slightly lower in SDR terms:}

- Lower projected budget outturn. The projected budget underrun in U.S. dollar terms is expected to be in the range of 3-5 percent of net administrative expenditures,

\footnotetext{
${ }^{3}$ The projection assumes that all available purchases are made under the arrangements recently approved for Georgia, Hungary, Iceland, Pakistan, the Seychelles and Ukraine, but does not assume drawings under precautionary arrangements.

${ }^{4}$ Actual performance of the IA from year to year will vary with market conditions. Consistent with past practice, the projected added value of 50 basis points is based on historical performance and is intended to provide an indication of the additional returns from the IA over the medium term. Further discussion on the performance of the IA will be provided in the semi-annual review of the IA (to be issued shortly).

${ }^{5}$ The SDR interest rate projection is based on market forward rates for the underlying three-month financial instruments in the SDR interest rate basket.
} 
with a central estimate of US\$35 million (SDR 22 million), largely owing to the higher than expected number of volunteers.

- Appreciation of the U.S. dollar. In SDR terms, most of the projected budget underrun is expected to be offset by the effects (SDR 20 million) of the appreciation of the U.S. dollar vis-à-vis the SDR during FY 2009. The updated average US\$/SDR exchange rate for FY 2009 is now projected at 1.59, compared with 1.65 at the beginning of the year.

- $\quad$ Restructuring costs. No change has been made to the projection for restructuring costs. As discussed in Annex 1, costs related to services from which the Fund will benefit, i.e., salaries and eligible benefits during the staff delay period, are recognized as the related expenditures are incurred. These costs, including the Fund's contributions to the staff retirement plan, are now expected to total SDR 47 million, of which SDR 19 million was recorded in the first half of FY 2009. Some of these costs will fall in FY 2010-11; amounts falling in outer years are likely to increase as a result of deferrals of separating staff being considered to address the institutional pressures associated with the global financial crisis. Given that the extent of deferrals is uncertain, of the above costs of SDR 47 million, staff has retained the original projection of SDR 39 million for FY 2009, which is broadly consistent with the pattern of actual costs observed in the first half. The remaining costs of SDR 8 million are expected to fall in FY 2010-11. 
Table 1. Projected Income Position-FY 2009

(In millions of SDRs)

$\begin{array}{lr}\text { Income shortfall projected in April 2008 } & -191 \\ \text { Income variances } & 196 \\ \text { Changes due to: } & 160 \\ \quad \text { New lending activity } & 42 \\ \text { Investment Account returns } & -6 \\ \text { SDR interest rate assumptions } & 2 \\ \text { Expenditure variances } & 22 \\ \text { Changes due to: } & -20 \\ \quad \text { Projected budget outturn } & \\ \text { US\$/SDR exchange rate } & \mathbf{7} \\ \text { Income now projected } & \end{array}$

7. Table 2 outlines the updated projections for FY 2009 and the actual outturn for the first half of the financial year. ${ }^{6}$ The assumptions are based on a central scenario in which repurchases for outstanding Fund credit take place as scheduled and projected lending activity includes disbursements under Stand-By Arrangements already approved (Annex 3). The updated projections do not include any provision for potential purchases under new arrangements not yet approved or under the Short-Term Liquidity Facility (SLF). ${ }^{7}$ While it appears likely that additional members will seek arrangements with the Fund during the second half of the financial year, the timing and amounts involved are uncertain. By way of illustration, if purchases in the second half of the year are higher than currently projected by, say, SDR 5 billion, the Fund's income would increase by approximately SDR 40 million, plus any additional income from surcharges. ${ }^{8}$

8. However, the risks to the outlook appear broadly balanced. On the one hand, income from lending could be higher if additional members enter into arrangements with the Fund during the second half or make purchases under the SLF. On the other hand, investment income could be significantly lower if bond yields reverse some of their recent decline, and

\footnotetext{
${ }^{6}$ The projected FY 2009 income and expenses are also presented in Annex 2 in a format similar to the IFRS financial statements presentation.

${ }^{7}$ See $A$ New Facility for Market Access Countries-The Short-Term Liquidity Facility (10/24/2008).

${ }^{8}$ This estimate includes the margin for the rate of charge and service charges, and assumes an end-January 2009 disbursement date (end of the third quarter of the 2009 financial year).
} 
the resumption of reimbursement to the GRA of the costs of administering the PRGF-ESF Trust may not occur as currently assumed.

Table 2. Projected Income and Expenditures (In millions of SDRs)

\begin{tabular}{lrrr}
\hline & & \multicolumn{2}{c}{ FY 2009 } \\
\cline { 2 - 4 } & Actual to end- & Initial & Current \\
Projections
\end{tabular}

1/ See Review of the Fund's Income Position for FY2008 and FY2009 (4/15/2008).

2 / Includes commitment fees, which are refundable (when disbursements take place) so income arises only if planned disbursement are not made.

3/ GRA interest-free resources currently approximate the SCA-1 balance.

4/ The projections remain unchanged from those made at the beginning of the year, which include reimbursement to the GRA of the costs of administering the PRGF-ESF Trust if the Fund adopts a decision authorizing the sale of the current stock of post-Second Amendment gold during FY 2009.

5/ Costs for which services were or are to be rendered and SRP contributions; these costs were not recognized in the FY 2008 restructuring provision.

\section{FY 2009 MIDYEAR REVIEW}

\section{The Executive Board adopted a margin for calculating the rate of charge for FY 2009 of 100 basis points over the SDR interest rate under the exceptional} circumstances clause of Rule I-6(4). ${ }^{9}$ Under this rule, the Executive Board is to review at midyear any change in the exceptional circumstances and decide whether the margin over the SDR interest rate determined at the beginning of the year shall be changed in light of the

\footnotetext{
${ }^{9}$ Rule I-6(4) was adopted to provide the basis for setting the margin on the basis of a target amount of net income for the year, and the midyear review was a safeguard clause for instances where the actual income position is significantly below initial projected amounts (Rule I-6(4)(b)(i)), and the Board would need to consider whether to increase the margin. Owing to the sharp decline in lending and the need to develop a new and sustainable income model, the rule was changed in April 2006 to allow the Executive Board to set the margin on a different basis in exceptional circumstances.
} 
actual income position for the first six months of the financial year. Consistent with the Board's previous discussions on the approach to setting the basic rate of charge under the new income model, staff considers that the exceptional circumstances under which the margin may be set on a basis other than estimated income and expenses and the net income target for the year still exist. Moreover, a margin of 100 basis points continues to represent a reasonable approach that is consistent with the income model principles that were recommended by the Crockett Committee and endorsed by the Board. Accordingly, no change in the margin is proposed.

10. Burden sharing. Since the Board review of the burden sharing mechanism earlier this year, burden sharing adjustments for deferred charges have declined and are projected to decline further. Adjustments to the rate of charge and the rate of remuneration have declined from 11 and 10 basis points, respectively, in the fourth quarter of FY 2008, to 9 and 8 basis points in the first half of FY 2009 (see Annex 4 for recent levels). Given the recent increase in Fund credit outstanding and the concurrent enlarged overall reserve tranche positions for members, the adjustments to the rates of charge and remuneration are expected to decline further to about 2 basis points in the second half of the financial year.

Table 3. FY 2009 Burden Sharing Adjustments

(In basis points)

\begin{tabular}{lcccc}
\hline & \multicolumn{2}{c}{ Actual } & \multicolumn{2}{c}{ Projected } \\
& Q1 & Q2 & Q3 & Q4 \\
\hline Adjustment to: & & & & \\
Rate of charge & 9 & 8 & 2 & 2 \\
Rate of remuneration & 8 & 7 & 2 & 2 \\
\hline
\end{tabular}




\section{Annex 1. Restructuring Costs}

The FY 2008 audited financial statements recognized a restructuring provision of SDR 68 million (about US\$111 million). The restructuring provision, recorded in accordance with International Financial Reporting Standards, included costs for which no services are expected to be rendered, i.e., the modified SBF payments and related costs, and costs associated with outplacement and retraining of separating staff. Staff reviewed the provision at midyear (end-October) based on finalized HR data (e.g., actual individual staff FY 2009 salaries, as determined in August this year) and found it to be adequate - the above costs for separating staff continue to be estimated at SDR 68 million.

SBF-related restructuring costs actually incurred through end-October 2008 amounted to some SDR 8 million (about US\$13 million)(see Table below). These costs mainly reflect salaries and eligible benefits, e.g., tax and education allowances and the Fund's contributions to the Medical Benefit Plan (MBP) for staff whose SBF period began prior to October 31, 2008. As noted, the above costs also include costs associated with outplacement and retraining of staff. These costs are being drawn against the FY 2008 restructuring provision.

Restructuring Costs (FY 2008-FY 2011)

(In millions of SDRs)

\begin{tabular}{cccc}
\hline & Initial & Updated & Actual to end- \\
Estimates 1/ & Estimates & Oct 2008 \\
\hline
\end{tabular}

$\begin{array}{llrr}\text { A. SBF and outplacement/retraining costs 2/ } & 76 & 68 & 8 \\ \text { B. Staff delay costs and SRP contributions 3/ } & 39 & 47 & 19 \\ \text { C. Total restructuring costs (A+B) } & 115 & 115 & 27\end{array}$

1/ See Review of the Fund's Income Position for FY 2008 and FY 2009 (4/15/08).

2/ These costs, primarily related to SBF payments, were included in the FY 2008 restructuring provision. The last column represents costs actually incurred against the provision, which through end-October 2008 amounted to SDR 8 million.

3/ The staff delay costs were not part of the FY 2008 restructuring provision and are recognized as they are incurred. The last column represents costs incurred through end-October 2008.

Costs related to services from which the Fund will benefit, i.e., salaries and eligible benefits during the staff delay period of up to 12 months, were not included in the FY 2008 provision. These costs will instead be recognized in FY 2009-FY 2011 as the related expenditures are incurred. ${ }^{10}$ In the six months to end-October 2008, these costs amounted to some SDR 15 million (about US\$24 million) and comprise primarily salaries, tax allowances for U.S. nationals, and the Fund's MBP contributions. In addition, a further SDR 4 million

\footnotetext{
${ }^{10}$ The restructuring budget was approved as a multi-year appropriation for FY2008-11. The majority of the staff delay costs and SRP contributions are expected to fall in FY 2009, but some costs may also occur in FY 2010-11 owing to deferral of staff separations by departments.
} 
(about US\$6 million) has been paid by the Fund as employer contributions to the staff retirement plan for separating staff (during both the staff delay and SBF period). ${ }^{11}$

Separation costs for three categories of volunteers, namely (i) department directors, (ii) staff leaving under rule of age 50, and (iii) staff on LWOP, totaling 48 staff, are charged to the administrative budget. Costs for these volunteers were not included in the original restructuring budget and therefore were not considered part of the base. However, in line with IFRS, no such distinction was made for financial reporting purposes, and as a result these amounts are included as part of restructuring costs. Further, under the IFRS accrual basis of accounting, restructuring costs related to SBF and outplacement/retraining costs were recognized in the FY 2008 financial statements.

Reconciliation of Restructuring Costs as at October 31, 2008

\begin{tabular}{lcc}
\hline & As at end-October 2008 \\
\hline A. FY 2009 execution of restructuring budget 2/ & US \$ millions & SDR millions 1/ \\
B. Voluntary separation costs charged to the FY 2008 administrative budget 3/ & $\mathbf{3 8 . 9}$ \\
C. Total restructuring costs (A+B) 4/ & 4.4 \\
D. SBF and outplacement/retraining costs against FY 2008 provision 5/ & 43.3 \\
E. Total FY 2009 financial reporting restructuring costs (C - D) 6/ & 34 \\
\hline
\end{tabular}

1/ The SDR equivalent is based on the average US\$/SDR exchange rate of 1.59.

2/ Total costs charged against the restructuring budget.

3/ Of the US\$8 million allocated to the FY 2008 administrative budget, some US\$4.4 million has been spent as at end October 2008.

4/ Represents the total costs actually spent as at end-October 2008 against the 492 separating staff.

5/ From a financial reporting perspective, SBF and outplacement/retraining costs are drawn against the FY 2008 restructuring provision.

6/ Represents staff delay costs and contributions to the staff retirement plan (see Table 2).

\footnotetext{
${ }^{11}$ These costs were also excluded from the restructuring provision because they are taken into account in the actuarial valuation for the Fund's pension plan and included in the IAS 19 expense.
} 
Annex 2. Projected Income and Expenses-FY 2009

(In millions of SDRs)

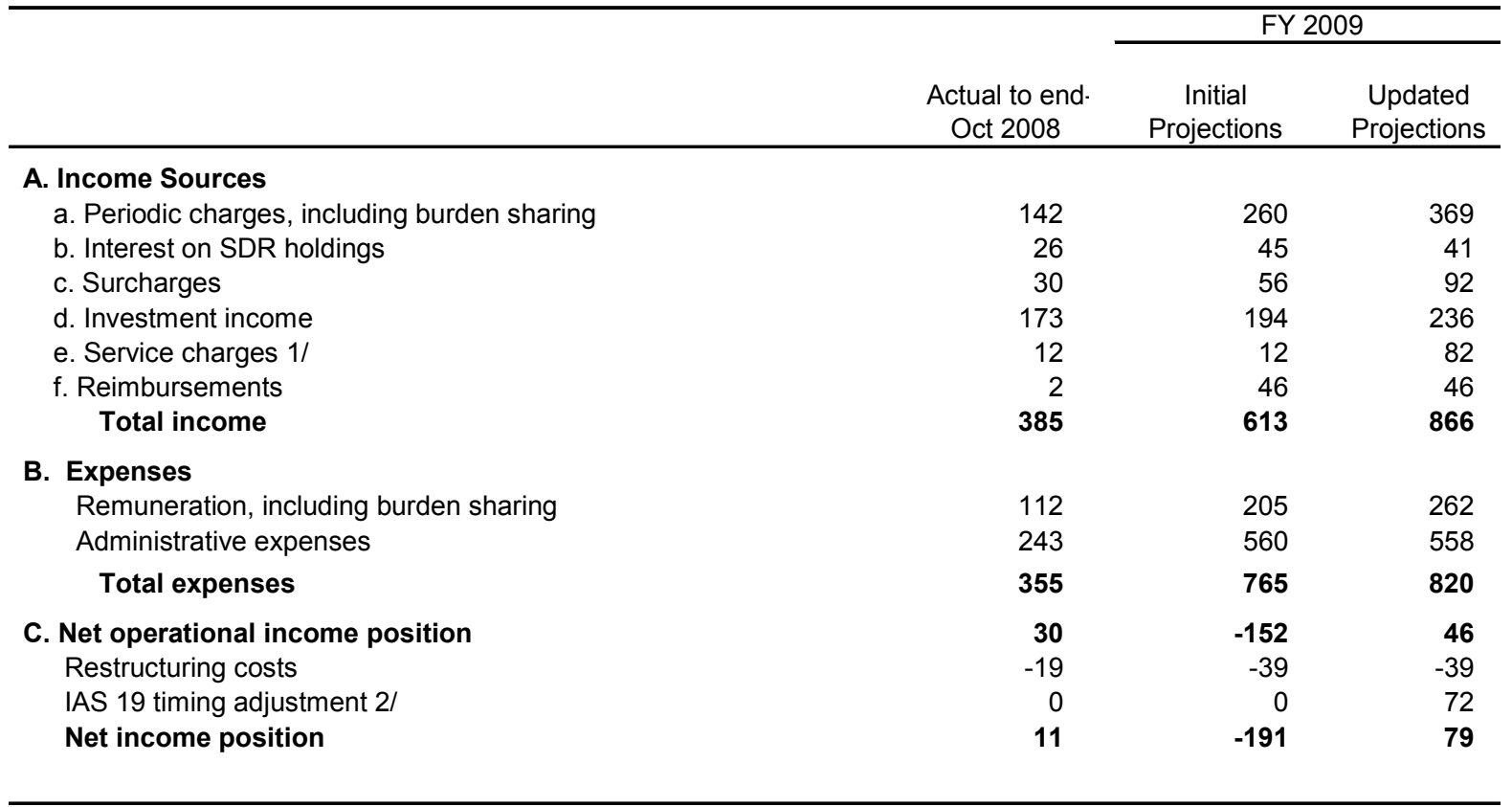

1/ Includes commitment fees, which are refundable (when disbursements take place) so income arises only if planned disbursement are not made.

2/ IAS 19 is the accounting standard under IFRS that prescribes the accounting treatment of pensions and employee benefits expenses, and involves actuary valuations. The audited IFRS financial statements at the financial year-end will include IAS 19 expenses. 
Annex 3. Assumptions Underlying the FY 2009 Projections

\begin{tabular}{|c|c|c|c|}
\hline & \multirow[b]{2}{*}{$\begin{array}{c}\text { Actual through } \\
\text { end-October } \\
2008 \\
\end{array}$} & \multicolumn{2}{|c|}{ FY 2009} \\
\hline & & $\begin{array}{c}\text { Initial } \\
\text { Projections }\end{array}$ & $\begin{array}{c}\text { Updated } \\
\text { Projections }\end{array}$ \\
\hline & & \multicolumn{2}{|c|}{ (In billions of SDRs) } \\
\hline \multicolumn{4}{|l|}{ Regular Facilities: } \\
\hline 1. Purchases (excl. reserve tranche purchases) & 2.4 & 2.3 & 16.3 \\
\hline 2. Repurchases & 0.9 & 1.7 & 1.8 \\
\hline 3. Average balances subject to charges & 7.6 & 7.2 & 12.6 \\
\hline 4. Average SDR holdings & 1.9 & 1.7 & 1.9 \\
\hline 5. Average remunerated positions & 8.2 & 7.8 & 13.3 \\
\hline \multirow[t]{2}{*}{ 6. Average investment account assets $1 /$} & 6.0 & 6.0 & 6.0 \\
\hline & \multicolumn{3}{|c|}{ (In percent) } \\
\hline Return on investments $2 /$ & 2.93 & 3.25 & 3.93 \\
\hline \multicolumn{4}{|l|}{ Average interest rates: } \\
\hline SDR interest rate and basic rate of remuneration & 2.81 & 2.75 & 2.20 \\
\hline Basic rate of charge & 3.81 & 3.75 & 3.20 \\
\hline Margin on the rate of charge & 1.00 & 1.00 & 1.00 \\
\hline
\end{tabular}

1/ The figures are based on a general assumption that investment income is transferred annually to the GRA.

2/ End-October figure is not annualized. 
Annex 4. Recent Average Burden Sharing Rates and FY 2009 Quarterly Rates (In basis points unless otherwise stated)

\begin{tabular}{|c|c|c|c|c|c|c|c|c|c|}
\hline & \multirow[t]{2}{*}{ FY03 } & \multirow[t]{2}{*}{ FY04 } & \multirow[t]{2}{*}{ FY05 } & \multirow[t]{2}{*}{ FY06 } & \multirow[t]{2}{*}{ FY07 } & \multirow[t]{2}{*}{ FY08 } & \multicolumn{3}{|c|}{ FY09 } \\
\hline & & & & & & & $\mathrm{H} 1$ & Q3 & Q4 \\
\hline & & & & & & & & (proje & cted) \\
\hline \multicolumn{10}{|l|}{ Rate of Remuneration 1/ } \\
\hline Total average adjustment & 10 & 9 & 12 & 23 & 23 & 14 & 8 & 2 & 2 \\
\hline Deferred charges & 2 & 1 & 2 & 5 & 13 & 14 & 8 & 2 & 2 \\
\hline SCA-1 & 8 & 8 & 10 & 18 & 10 & - & - & - & - \\
\hline \multicolumn{10}{|l|}{ Rate of Charge 1/ } \\
\hline Total average adjustment & 10 & 8 & 11 & 19 & 23 & 16 & 9 & 2 & 2 \\
\hline Deferred charges & 2 & 1 & 2 & 4 & 13 & 16 & 9 & 2 & 2 \\
\hline SCA-1 & 8 & 7 & 9 & 15 & 10 & - & - & - & - \\
\hline Average SDR interest rate (in percent) & 2.06 & 1.58 & 2.09 & 2.93 & 3.96 & 3.64 & 2.81 & 1.60 & 1.60 \\
\hline Average basic rate of charge (in percent) & 2.54 & 2.09 & 3.01 & 4.00 & 5.04 & 4.72 & 3.81 & 2.60 & 2.60 \\
\hline
\end{tabular}

1/ The average rates have been calculated using the quarterly burden sharing rates and SDR interest rates. 